\title{
First detection of tomato spotted wilt virus in tomato in Venezuela
}

\author{
Eduardo Rodríguez-Román ${ }^{1}$. Alexander Mejías ${ }^{1}$ - Edgloris E. Marys ${ }^{1}$ \\ Published online: 22 May 2018 \\ (C) Società Italiana di Patologia Vegetale (S.I.Pa.V.) 2018
}

In May 2017, symptomatic tomato (Solanum lycopersicum L.) plants cv. Shanty (Roma) were observed in a commercial plantation at Quibor, Lara State, Venezuela. Plants exhibited symptoms of leaf mottling, yellowing, bronzing, necrotic spots, wilting and deformed fruits with chlorotic spots. Symptoms were noticed in roughly $70 \%$ of plants. Incidence of thrips (Frankliniella occidentalis) was also observed in the field. Given the symptoms recorded and the prevalence of thrips, tospovirus infection was suspected. Total RNA was extracted from thirteen symptomatic plants and analyzed by RT-PCR using universal tospovirus primers L1/L2 (Chatzivassiliou et al. 2000). DNA fragments of the expected size (276 bp) were amplified from all samples. One PCR product was customsequenced (Macrogen, South Korea) and the sequence was deposited in GenBank as accession No. MF806381. Sequence analysis showed that the fragment sequence shared best nucleotide sequence identity (99\%) to tomato spotted wilt virus (TSWV, genus Tospovirus, family Bunyaviridae) isolates from different hosts from Venezuela (KP006412, KP006413,KC202213.1) and Russia (JX452818.1). Further TSWV identity was ascertained by RT PCR assays with primers CP1-TSWV/CP2-TSWV (Chatzivassiliou et al. 2000). A single DNA product of $823 \mathrm{bp}$ was amplified from all samples. BLAST analysis of the consensus sequence of the $\mathrm{N}$ gene of this isolate (MF806380) revealed a sequence identity of 97-99\% with known TSWV isolates. TSWV natural occurrence in pepper and ornamental crops has been previously reported from Venezuela (Marys et al. 2014; PérezColmenarez et al. 2015); however it should be noted that this is the first report of TSWV from tomato in Venezuela. Presence of TSWV has important implications for the complex phytosanitary situation of the tomato crops, as the virus could be coinfecting this crop together with begomoviruses present in the country with a significant impact on production. Results of this study may help growers devise appropriate TSWV disease management strategies and suggest the importance of a vigilant survey to monitor potential dissemination of TSWV to other tomato-growing areas in Venezuela.

\section{References}

Chatzivassiliou EK, Weekes R, Morris J, Wood KR, Barker I, Katis NI (2000) Tomato spotted wilt virus (TSWV) in Greece: its incidence following the expansion of Frankliniella occidentalis, and characterisation of isolates collected from various hosts. Ann Appl Biol 137:127-134

Marys E, Mejías A, Rodríguez-Román E, Avilán D, Hurtado T, Fernández A, Zambrano K, Garrido M, Brito M (2014) The first report of tomato spotted wilt virus on gerbera and chrysanthemum in Venezuela. Plant Dis 98:1161

Pérez-Colmenarez Y, Mejías A, Rodríguez-Román E, Avilán D, Gómez JC, Olachea JE, Zambrano K, Marys E (2015) Identification of Tomato spotted wilt virus associated with fruit damage during a recent virus outbreak in pepper in Venezuela. Plant Dis 99:896
Edgloris E. Marys

edgloris@gmail.com

1 Centro de Microbiología y Biología Celular, Laboratorio de Biotecnología y Virología Vegetal, Instituto Venezolano de Investigaciones Científicas (IVIC), Caracas 1020-A ZIP 20632, Venezuela 